\title{
ARTIKEL
}

\section{CLASSROOM INTERACTION IN THE ENGLISH SUBJECT FOR THE THENTH GRADE OF SMA N 1 SALAK PAKPAK BHARAT}

\author{
Disusun dan Diajukan oleh: \\ Dirgahayu Tumangger \\ NIM. 2122121014 \\ Telah diverifikasi dan dinyatakan memenuhi syarat \\ untuk diunggah pada jurnal online
}

Medan, 10 Januari 2018

Menyetujui

Dosen Pembimbing Skripsi I

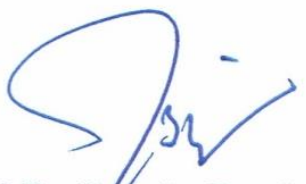

Prof. Dr. B smin Gurning, M.Pd.

NIP. 195904131986011001
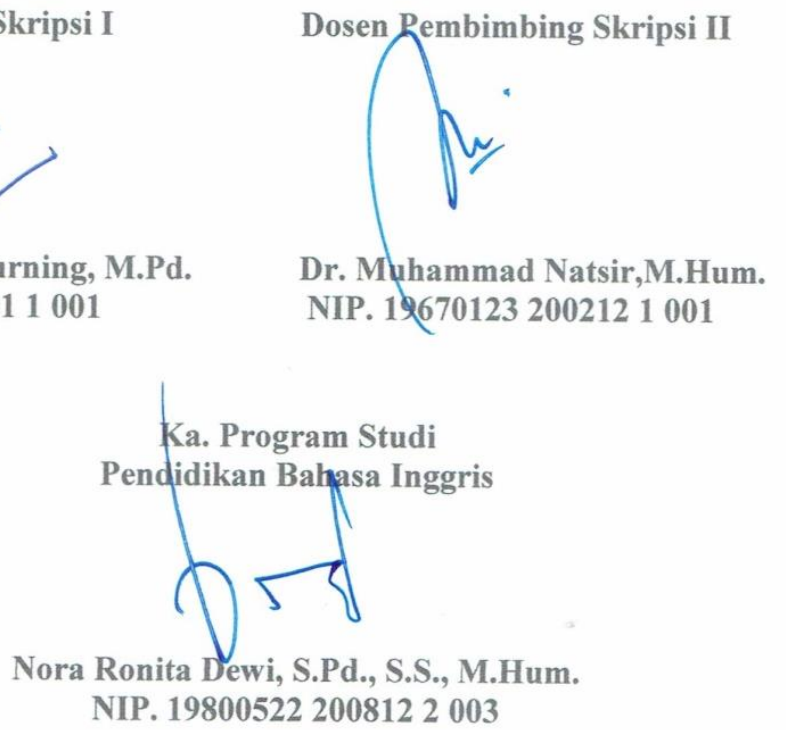


\title{
CLASSROOM INTERACTION IN THE ENGLISH SUBJECT FOR THE TENTH GRADE OF SMA N 1 SALAK PAKPAK BHARAT
}

\author{
*Dirgahayu Tumangger \\ ***Busmin Gurning \\ ***Muhammad Natsir \\ Fakultas Bahasa dan Seni \\ Universitas Negeri Medan
}

\begin{abstract}
Tumangger, Dirgahayu. 2122121014. Classroom Interaction In The English Subject For The Tenth Grade Of SMA N 1 Salak Pakpak Bharat. A Thesis. Faculty of Languages and Arts, State University of Medan. 2017.
\end{abstract}

This study aimed at finding out the categories of teacher and students talk and the percentage of teacher and students talk during classroom interaction. This study was conducted by using descriptive qualitativedesign. The subjects of this study were the tenth grade students of SMAN 1 Salak and the English teacher who taught at that class in 2017/2018 academic year. The data were the utterances of both teacher and students during the classroom interaction process which were collected by using observation and recorded by using smartphone and recorded it about three meetings.The data collected were analyzed by using Flanders Analysis formulate. The findings of the study showed Analysis showed, there are ten categories of students and teachers talk that could be found during the classroom interaction and the percentage of each of category was: 2,05\% for accepting feeling, $5.88 \%$ for praising and encouraging, 5,29\% for accepting students' ideas, $11,17 \%$ for asking question, $11,76 \%$ for lecturing, $8,52 \%$ for giving direction, $14,41 \%$ for criticizing, $32,35 \%$ for students talk response, $6,17 \%$ student talk initiation and2,35\% for silence and confusion.so the teacher talk percentage was about $60,3 \%$ and $38,52 \%$ for student.

Keywords: classroom interaction, Flanders interaction analysis category system

\footnotetext{
*Graduate Status

**Lecturer Status
} 


\section{Introduction}

Classroom interaction is the communication occurs in the classroom at school. While transferring their knowledge, teacher absolutely interacts with students by language. Without communication by language in the classroom teachers are not able to evaluate the learning process. Moreover they also must know what actually their students problem in learning and how to find out the solution together through communication in the classroom interaction. Classroom interaction the teacher talk should less than $25 \%$ while the students talk must be $75 \%$ of overall the interaction. However in SMA N 1 Salak, the percentage of teacher talk is too dominant.

This study are going to analyze the category of teacher and students talk and then the percentage of teachers talk. The researcher will analyze the classroom interaction which is happen in SMA N 1 Salak by using Flanders interaction analysis category.

Ned A Flanders introduces a theory to analyze the teaching behavior, especially classroom interaction, namely Flanders Interaction Analysis Category System. It was divided into ten categories, 7 categories belong to teacher, 2 to students and the rest was the silent and confusion. This theory was very helpful to the researchers who interest to conduct classroom interaction research. For example, by FIACS teachers know their percentage in teaching, whether too dominated or not in the classroom interaction.

It was important to conduct a research of classroom interaction analysis, because teacher would not realize their weakness in teaching without analyzing it. The atmosphere of interaction will be known by analysis. Whether the teacher spent too 
much talking and the other hand students just spent a very little or even the student spent too much talking. Through analyzing, teacher and student get what they are saying in classroom recently and the most important thing, they are able to improve themselves as soon as possible.

According to Rivers in Tuan and Nhu (2010) interaction is important because students can increase their language store as they listen to others including both the teacher talk and output of their fellow students in discussions or problem solving tasks through interaction, and they can use all they have learned in real-life exchanges where they express their views and use the language for communication.

The classroom is the place where teachers and students come together and language learning is supposed to happen. So, it can be said that, classroom interaction is an interaction between lecturer and students that happens when they participated in the classroom. It means that classroom interaction is all of interactions that occur in the learning and teaching process. Classroom interaction has to be managed by everyone taking parts both of teacher and students, not just by the teacher because interaction is obviously not something people do alone, but something people do together collectively.

Interaction is the collaborative exchange thoughts feelings, or idea between two or more people, resulting in a reciprocal effect on each other. Theories of communicative competence emphasize the importance of interaction as human beings use language in various contexts to negotiate, meaning or simply stated to get and idea out of one person's head and into the head of another person and vise versa. 
From the very beginning of language study classroom should be interactive. wilga rivers puts it this way:

Through interaction, students can increase their language store as they listen to or read authentic linguistic material, or even the output of their fellow students in discussions, skits, joint problem-solving task or dialogue journals. In interaction, students can used all they process of the language- all they have learned or casually absorbed- in real life exchanges.

Beside that, Chaudron in Kaur and Talat (2015) states that interaction is viewed as significant because it is argued that:

1. Only through interaction, the learner can decompose the teaching language structures and derive meaning from classroom events.

2. Interaction gives learners the opportunities to incorporate teaching language structures into their own speech (the scaffolding principles) and

3. The meaningfulness for learners of classroom events of any kind, whether thought of as interactive or not will depend on the extent to which communication has been jointly constructed between the teacher and learners

\section{Classroom Interaction Analysis}

In the teaching learning classroom process, the teacher tries to transfer their knowledge to students. This process must be by interaction through language with students in the classroom. According to Flanders in Arockiasamy defines teaching as an interactive process, interaction means participation of teacher and students in the 
process of teaching, in this process, teacher influences the students; students also interact with the teacher. Interaction takes place among the students themselves also. It means, in the process of teaching everybody interacts with every other person involved in the process. Interaction occur between teacher and students when the teacher influences students through lecture, ask question, criticizing, and giving direction. Student gives their responses and reacted to the teacher's lecture and questions.

1. In order to get the clear explanation and to understand while interpret interaction to the number categories, Flanders in Arockiasamy (2016) elaborates in the following:

2. In this method of analysis, the first four categories represent the teacher's indirect influence. Indirect talk consist of Accepts Feelings, : indirect talk Praise or Encouragement, Accepts or Uses ideas of Pupils, Asking Questions, and Lecturing /Lecture, Giving Directions, Criticizing or Justifying Authority for direct talk. Pupil Talk Response and Pupil Talk Initiation for students talk and Silence or Pause or Confusion (1 category)

\section{Method}

The design of this research was descriptive qualitative design. The study was focused on classroom interaction analysis. The researcher observed the teachers' and students' talk during having a class in teaching and learning process. By using Flanders's Interaction Analysis Categories (FIAC), the researcher described the result of this research by showing what were the 
categories of teacher and student's talk that they used in the class and what was the percentage of teacher's and students' talk during the learning process.

The Sources of Data was in the form of words. The data were collected from the interactions which had appear during learning process in SMA N 1 Salak in the academic year 2017/2018. The researcher involved1 teacher and one class in three meetings.

The data were collected by observing one class by using two methods which included observation tally sheet, and recording (audio and video recording). According to Best (2002), the data from observation consist of data descriptions of people's activities, actions and the full range of interpersonal interactions and organizational processes that are part of observable human experience.

The procedure of the research

1. The researcher came to the class and sit at the backside of the classroom.

2. The researcher prepared a phone to record the interaction.

3. The researcher recorded the whole interaction during learning process.

4. The researcher converted the recording into transcript.

5. The researcher put code on each teachers and students talk.

6. The researcher put the plotting of the coded data in matrix of Flander interaction analysis to indicate the category 
7. The researcher calculated the teacher and students talk during teaching and learning process by using Flander's formulas.

\section{DATA AND DATA ANALYSIS}

The data of this study were collected from one class of English subject in SMA N 1 Salak in the academic year 2017/2018. In this research, to get the data, the researcher recorded whole of teaching-learning activities ofclass from the beginning until the end about three meetings and the researcher made the transcript of the recordings in order to find the category of student talk and teacher talk that occured while teaching-learning process, and to find the percentage of teacher talk and student talk and also to find the characterics of teaching which occured during teachinglearning process of English classes in SMA N 1 Salak in the academic year $2017 / 2018$.

As mentioned in the scope of this study, the data of this research only focus on the interaction that teacher and students do in the classroom. The reseacher analyzed the data based on the Flanders Interaction Analysis System Category (FIACS).

After analyzing the data, observing and calculating the percentage in the classroom interaction in SMA N 1 Salak, the findings of the result can be presented as folliows:

1. Ten types of interaction in the Flanders Interaction Analysis Category (FIACS) namely, accepting feeling, praising and encouraging, accepting students' ideas, asking question, lecturing, giving direction, criticizing, students talk response, student 
talk initiation, and silence and confusion appeared while teaching learning process in SMA N 1 Salak. By persentation 2,05\% for accepting feeling, 5.88\% for praising and encouraging, 5,29\% for accepting students' ideas, $11,17 \%$ for asking question, $11,76 \%$ for lecturing, $8,52 \%$ for giving direction, $14,41 \%$ for criticizing, $32,35 \%$ for students talk response, $6,17 \%$ student talk initiation and $2,35 \%$ for silence and confusion.

2. The interaction between teacher and students in teaching- learning process is dominated by the teacher. It can be seen from the percentage of teacher talk and student talk in the class. The teacher spent $60,3 \%$ of interaction while students only spent $32,35 \%$ of interaction while teaching-learning process and 2,35\% for silence or confusion.

Based on the Flanders theory, there are ten categories of interaction namely learning proccess, accepting feeling, praising and encouraging, accepting students' ideas, asking question, lecturing, giving direction, criticizing, students talk response, student talk initiation, and silence and confusion. After analyzing the data, all of the categories of interaction on flanders theory occured while teaching-learning process. Based on the result, students talk response is the highest type of student talk by $32,35 \%$. from the result above, the students spoke in the class if the teacher asked them to speak, or spoke in the class just to answer the questions from the teacher . According to Van Lier (1996) in tuan and nhu, this model has been characterized as a "closed, rather than an open, discourse format". Therefore, it makes the lesson less communicative. 
Good interaction between teacher and students is needed in the class. So, the students are expected more active in the class than the teacher. It is also important to the teacher and to the students to know the percentage of the interaction that they did in the classroom. The benefit of knowing the percentage for the teachers, by knowing the percentage of the interaction of their speaking in the class, they will know about the percentage of their way of teaching is ideal or not.Based on Wright theory (1975) it is said ideal if the teacher spends no more $25 \%$ of interaction and if the teacher spends more than $25 \%$ of interaction, it can be said not ideal. If it is not ideal, the teachers can improve their performance, and creates the good atmosphere to interact the students in the teaching-learning process by making the class more interactive.

After conducting the research and calculating the interaction in the class, the researcher found that teacher talk was still high.It can be seen from the percentage of teacher talk and student talk in the class. The teacher spent $60,3 \%$ of interaction while students only spent $32,35 \%$ of interaction while teaching-learning process and $2,35 \%$ for silence or confusion. So, it can be concluded that teaching - learning process of English Subject in SMA N 1 Salak was still in teacher's dominant activity. Based on the result, the teacher still need to improve her performance while teachinglearning process and to help students get their goal by giving more opportunities to the students to speak in the class while teaching-learning process.

\section{Conclusions}

Based on the data analysis and the results of the study, the researcher concludes that : 
All of the types of interaction based on Flanders Interaction Analysis Category System (FIACS), namely accepting feeling, praising and encouraging, accepting students' ideas, asking question, lecturing, giving direction, criticizing, students talk response, student talk initiation, and silence and confusion appeared during teachinglearning process in SMA N 1 Salak. By persentation 2,05\% for accepting feeling, $5.88 \%$ for praising and encouraging, 5,29 for accepting students' ideas, $11,17 \%$ for asking question, $11,76 \%$ for lecturing, $8,52 \%$ for giving direction, $14,41 \%$ for criticizing, 32,35\% for students talk response, $6,17 \%$ student talk initiation and 2,35\% for silence and confusion.

The interaction between teacher and students in English classes are not ideal beacause the teacher was dominant than students in teaching- learning process in. The teacher almost spent $60,3 \%$ of interaction in the classroom while students only spent $38,52 \%$ of interaction.

\section{References}

Acroksiamy, Educational Technology, viewed.21 August2017.

Brown, H.D 2007.Principles of Language Learning and Teachiong, Fifth Edition, Pearson Education, United States of America.

Dagarin, M. 2004. Classroom Interaction and Communication Strategies in Learning English as a Foreign Language', pp.3-4.

Flanders, N. A. (1970). Intent, action and feedback: A preparation for teaching. Journal of Teacher Education, 14, 251-260. 
Harmer, J 2001.How to Teach English, Seventh Impression,Pearson Education Limited, Malaysia.

Kaur and tatla. 2015. Flanders Classroom Interaction Category System As A Tool Of Tteaching.Associate Professor, Department of Education C.S., Punjabi University Patiala. (Volume 2, no:9)

Koul, L 1996. Methodology Educational Research, Third revised,Vikas Publishing House, New Delhi.

Richard, Jack. C. and Richard Schmidt. 2002. Longman Dictionary ofLanguage Teaching and Applied Linguistics (Third Edition). London:Longman, Pearson Education.

Rivers, Wilga M. 1987. Interactive Language Teaching. Interaction as the Keyto Teaching sLanguage for Communication.New York: CambridgeUniversity Press.

Tuan and Nhu. 2010. Theoretical Review on Oral Interaction in EFL Classroom. Canada.(Vol, 4 No:1)

Ur, Penny. 1996. A Course in Language Teaching: Practice and Theory. New York: Cambridge University Pers. 